\title{
Social Justice and Capitalism: An Assessment of the Teachings of Pope Francis from a Law and Macroeconomics Perspective
}

\author{
Steven A. Ramirez*
}

CONTENTS

INTRODUCTION

I. THE TEACHINGS OF POPE FRANCIS ON UNFETTERED CAPITALISM. 1235

II. THE TEACHINGS OF ECONOMICS ON UNFETTERED CAPITALISM ... 1247

III. THE ECONOMIC REALITY OF SOCIALLY JUST SYSTEMS ................ 1254

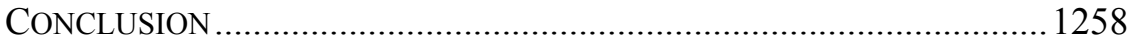

\section{INTRODUCTION}

Many commentators do not hesitate to level criticism against the core teachings of Pope Francis regarding high economic inequality and climate change. ${ }^{1}$ One U.S. Senator thought that Pope Francis should "leave science to the scientists" with respect to global warming. ${ }^{2}$ A writer for Forbes suggests Pope Francis simply "doesn't understand basic economics." 3 One high-profile economist suggests Pope Francis does not understand market theory very well. ${ }^{4}$ Fundamentally, however, these critiques miss His

* Professor of Law, Loyola University Chicago, and Director, Business Law Center. Marko Stojkovic provided helpful research assistance for this article. Sramir3@luc.edu.

1. Jeff Nesbit, Opinion, The Pope's Critics Have It Wrong, US News \& WORLD REP. (Sept. 24, 2015), https://www.usnews.com/opinion/blogs/faith-matters/2015/09/24/pope-francis-critics-have-itwrong-on-climate-change-and-capitalism [https://perma.cc/UMX3-BAKF] (“They've criticized his 'leftist' politics, analyzed his take on capitalism, dissected his competency on the science of climate change and questioned his understanding of energy poverty.").

2. Jane C. Timm, Santorum to Pope Francis: 'Leave Science to the Scientists' MSNBC (June 3, 2015), http://www.msnbc.com/msnbc/santorum-pope-francis-leave-science-the-scientists [https://perma.cc/UEU6-78XS].

3. Tim Worstall, Pope Francis Doesn't Really Understand This Economics Thing, Does He?, FORBES (Nov. 22, 2014), https://www.forbes.com/sites/timworstall/2014/11/22/pope-francis-doesntreally-understand-this-economics-thing-does-he/\#753c19016062.

4. William D. Nordhaus, The Pope \& the Market, N.Y. Rev. BooKs (Oct. 8, 2015), http://www.nybooks.com/articles/2015/10/08/pope-and-market/ [https://perma.cc/724L-SRPF] ("Unfortunately, Laudato $\mathrm{Si}$ ' does not recognize the fact that environmental problems are caused by market distortions rather than by markets per se.”). 
Holiness's main point: left to the dynamics currently in place, high economic inequality and climate change threaten the ultimate failure of capitalism and even mass death. ${ }^{5}$ As such, these problems cry out for a spiritual and moral voice, and require a multidisciplinary approach to highly complex learning from across the spectrum of knowledge, not just constipated notions of microeconomic theory. ${ }^{6}$

In order to avert catastrophe, the Pope relies upon longstanding Jesuit notions of social justice as embodied in traditional Catholic teachings, which also coincide with the most macroeconomically and politically robust forms of capitalism. ${ }^{7}$ More specifically, longstanding teachings of the Catholic Church regarding social justice yield high levels of inequality-adjusted human development, thereby stabilizing the political foundations of capitalism for maximum sustainability of any capitalistic system. $^{8}$ And, perhaps more than any other economic metric,

5. Many economists recognize that the Pope's focus on macroeconomic issues makes sense particularly in the context of the United States today. E.g., Daniel Altman, Pope Francis Is a Great Economist, FOREIGN POL'Y (Sept. 15, 2015), http://foreignpolicy.com/2015/09/25/pope-francis-is-agreat-economist-poverty-inequality-productivity/ [https://perma.cc/3JJX-EABN].

6. By its very nature, the link between inequality and environmental degradation, a cornerstone of the teachings of Pope Francis, requires a wide array of disciplines to address and resolve it. See Pope Francis, Address of the Holy Father at Meeting with the Members of the General Assembly of the United Nations Organization (Sept. 25, 2015), http://w2.vatican.va/content/francesco/en/ speeches/2015/september/documents/papa-francesco_20150925_onu-visita.html [https://perma.cc/ RPV2-N98F] (Economic and social exclusion is a complete denial of human fraternity and a grave offense against human rights and the environment. The poorest are those who suffer most from such offenses, for three serious reasons: they are cast off by society, forced to live off what is discarded and suffer unjustly from the abuse of the environment. They are part of today's widespread and quietly growing "culture of waste".).

7. A Jesuit priest, Luigi Taperelli, is widely thought to have coined the term "social justice." Thomas C. Behr, Luigi Taparelli and a Catholic Economics, 14 J. MARKeTs \& MORALITY 607, 608 (2011) ("Taparelli coined the term social justice to refer to the justice due between associations on the same, or at greater or lesser levels, of the social hierarchy.").

8. As early as 1891, the Catholic Church, through Pope Leo VIII, spoke out against unchecked capitalism and its tendency to lead to excessive concentrations of power and misery at opposite ends of the economic spectrum. See Pope Leo XIII, Encyclical Letter, Rerum novarum: Encyclical of Pope Leo XIII on Capital and Labor, para. 2 (1891) http://w2.vatican.va/content/leo-xiii/en/encyclicals/ documents/hf_1-xiii_enc_15051891_rerum-novarum.pdf [https://perma.cc/8D5X-P39P] [hereinafter Pope Leo XIII, Rerum Novarum] ([S]ome opportune remedy must be found quickly for the misery and wretchedness pressing so unjustly on the majority of the working class. ... [I]t has come to pass that working men have been surrendered, isolated and helpless, to the hardheartedness of employers and the greed of unchecked competition. The mischief has been increased by rapacious usury, which, although more than once condemned by the Church, is nevertheless, under a different guise, but with like injustice, still practiced by covetous and grasping men. To this must be added that the hiring of labor and the conduct of trade are concentrated in the hands of comparatively few; so that a small number of very rich men have been able to lay upon the teeming masses of the laboring poor a yoke little better than that of slavery itself.). See also Gerald S. Twomey, Pope John Paul II and the "Preferential Option for the Poor", 45 J. CATH. Legal StuD. 321, 327-28 (2006) ("John Paul proposed that unjust distribution of wealth and engrained, structural injustice require the Church's spirited advocacy for - and in defense of - the rights of the poor."). 
inequality-adjusted human development is the most meaningful, for it measures how well the mass of human beings in a given economic system fare in terms of material prosperity, educational attainment, and longevity. ${ }^{9}$ Social justice leads to high and environmentally sustainable human development. ${ }^{10}$ After all, no amount of macroeconomic growth alone can save humanity if it significantly degrades the biosphere's ability to sustain human life. ${ }^{11}$

The recent writings of Pope Francis on social justice and the environment articulate a vision of global capitalism that is fully consistent with the best learning on the ability of capitalism to deliver rising living standards to the mass of humanity, broad-based economic opportunity to maximize human potential, and sustainable economic growth. ${ }^{12}$ Too often the Pope's vision suffers unwarranted criticism that somehow his values evince an inherent hostility to capitalism simply because he takes a broadly inclusive view of capitalism and suggests that economic growth also

9. Douglas A. Hicks, The Inequality-Adjusted Human Development Index: A Constructive Proposal, 25 World DEV. 1283, 1283, 1293-94 (1997) ("In dimensions of life such as income, education, and health/longevity, inequality is significant for economic and ethical analyses.").

10. The United Nations Human Development Programme defines Inequality-Adjusted Human Development Index (IHDI) through an index designed as follows:

The IHDI combines a country's average achievements in health, education and income with how those achievements are distributed among country's population by "discounting" each dimension's average value according to its level of inequality. Thus, the IHDI is distribution-sensitive average level of HD [human development]. Two countries with different distributions of achievements can have the same average HDI [human development index] value. Under perfect equality the IHDI is equal to the HDI, but falls below the HDI when inequality rises.

Inequality-Adjusted Human Development Index (IHDI), United NATIONS Dev. Programme, http://hdr.undp.org/en/content/inequality-adjusted-human-development-index-ihdi

[https://perma.cc/FZ9K-TVZH]. I posit that law should constrain and channel the exercise of power for the purpose of maximizing a given society's IHDI in order to ensure the health, education, and prosperity of its citizenry as a whole in a sustainable manner. See Steven A. Ramirez, Rodrigo's Abstraction: Capitalism, Inequality, and Reform over Time and Space, 50 WAKE FOREST L. REV. 187, 187-92 (2015).

11. Chris Hope \& Kevin Schaefer, Economic Impacts of Carbon Dioxide and Methane Released from Thawing Permafrost, 6 NATURE: Climate ChANGe 56 (2016) (estimating economic damage to the environment from global warming to amount to a net present value of $\$ 43$ trillion). Citigroup estimates costs of $\$ 44$ trillion "if the scientists are correct." Energy Darwinism II, CITIGROUP 8 (2015), https://climateobserver.org/wp-content/uploads/2015/09/Energy-Darwinism-Citi-GPS.pdf

[https://perma.cc/TPY3-UBEL]. Another recent study suggests potential productivity losses from global warming that could reduce global GDP by $23 \%$. Marshall Burke et al., Global Non-Linear Effect of Temperature on Economic Production, 527 NATURE 235, 235 (2015). The release of methane from thawing permafrost threatens runaway "apocalyptic" global warming, which some scientists argue doubled global temperatures and nearly wipedout life 250 million years ago. Uwe Brand et al., Methane Hydrate: Killer Cause of Earth's Greatest Mass Extinction, 25 PALAEOWORLD 496 (2016).

12. This article limits its focus to secular macroeconomic issues and human development concerns. It does not directly address moral or philosophical debates. 
achieve environmental sustainability. ${ }^{13}$ These views demonstrate no hostility to capitalism per se but instead constitute a coherent and politically attainable vision of capitalism that articulates the best long-term ability of capitalism to serve human needs. ${ }^{14}$

Empirical studies suggest that in order for capitalism to achieve long-term economic growth, broad empowerment and inclusive economic opportunities must spur innovation, which in turn is the core feature of capitalism that enables long-term growth. ${ }^{15}$ Further, insisting upon the internalization of all costs, including environmental costs, into the price of all goods and services assures that those using resources deploy them efficiently and that more environmentally sound products compete on a level playing field. ${ }^{16}$ This is a bedrock feature of market theory and lends powerful support to the teachings of Pope Francis on the need to guard

13. E.g., Chris Matthews, Does Pope Francis Hate Capitalism?, ForTune (Sept. 20, 2015), http://fortune.com/2015/09/20/does-pope-francis-hate-capitalism/ [https://perma.cc/S6TF-BRUL] ("Francis has used unusually colorful language in his exhortations against global poverty and 'unfettered capitalism,' which has rankled Americans of a free-market bent."). See also Robert P. Barnidge, Jr., Against The Catholic Grain: Pope Francis Trumpets Socialism Over Capitalism, FORBES (Mar. 11, 2016), https://www.forbes.com/sites/realspin/2016/03/11/against-the-catholicgrain-pope-francis-trumpets-socialism-over-capitalism/\#42d3ee042d3e ("Phrased as it is, the Pope's call for a 'truly communitarian economy' tempts socialist revolution.").

14. For example, in Bolivia, His Holiness stated:

Time, my brothers and sisters, seems to be running out; we are not yet tearing one another apart, but we are tearing apart our common home. Today, the scientific community realizes what the poor have long told us: harm, perhaps irreversible harm, is being done to the ecosystem. The earth, entire peoples and individual persons are being brutally punished. And behind all this pain, death and destruction there is the stench of what Basil of Caesarea called "the dung of the devil". An unfettered pursuit of money rules. The service of the common good is left behind. Once capital becomes an idol and guides people's decisions, once greed for money presides over the entire socioeconomic system, it ruins society, it condemns and enslaves men and women, it destroys human fraternity, it sets people against one another and, as we clearly see, it even puts at risk our common home.

Pope Francis, Address at Expo Fair at World Meeting of Popular Movements, (July 10, 2015), http://www.news.va/en/news/pope-francis-speech-at-world-meeting-of-popular-mo

[https://perma.cc/MX79-V6H9]. While conservatives may find the language distasteful, it simply misconstrues the Pope's words to argue that he evinces any hostility to capitalism rather than rampant materialism.

15. SteVEn A. RAMIREZ, LAWLESS CAPITALISM 17-47 (2013) (explaining the key role of human capital and the generation of ideas plays in sustainable, long-term macroeconomic growth).

16. Do Economists All Favour a Carbon Tax? Most Do, with Good Reason, ECONOMIST (Sept. 19, 2011), http://www.economist.com/blogs/freeexchange/2011/09/climate-policy [https://perma.cc/ 27H3-7QBP] ("A carbon tax is also the easiest way to capture whatever low-hanging emissionreduction fruit is out there. Right now, consumers are generally indifferent between similarly-priced goods with wildly different carbon profiles. A carbon tax encourages consumers to realise the easy carbon gains available from switching to good low-carbon substitutes."). A carbon tax also encourages energy innovation and therefore economic growth. Joshua Meltzer, A Carbon Tax as a Driver of Green Technology Innovation and the Implications for International Trade, 35 ENERGY L.J. 45, 67-68 (2014) ("The United States should introduce a carbon tax. This would be a means to raise revenues to address the fiscal deficit and complement bipartisan efforts to incentivize innovation in the green technology sector in an effort to reduce $\mathrm{CO}_{2}$ emissions."). 
against environmental abuse and degradation. ${ }^{17}$ Indeed, environmental constraints on growth arguably become greater the less regulation and law operates to internalize costs that producers could otherwise externalize to future generations or vulnerable populations. ${ }^{18}$ Without core values of inclusion and sustainability, capitalism risks devolution to an instrument of oppression for the powerful at the expense of long-term social welfare for humanity as a whole. ${ }^{19}$ High economic inequality facilitates the use of power for profit at great expense to the common good and the environment. ${ }^{20}$ That stark reality undermines the viability of capitalism from a political perspective, suggesting that unfettered capitalism may prove to be the ultimate threat to capitalism, as history amply demonstrates.

The first part of this Article will synthesize the key teachings of Pope Francis from his most important statements on economic structures and social justice and situate these teachings within contemporary economic realities and traditional social justice teachings. Part II of this Article will demonstrate that the Pope's teachings on social justice fundamentally reflect the best learning from economists on how to sustain economic growth. Part III of this Article will show that nations that undertake policies to pursue the fundamental tenets of the Pope's teachings (such as minimizing childhood poverty) also perform the best in achieving high human development outcomes for the mass of their citizens. This Article

17. Id. At no time has Pope Francis made any statement suggesting a material regression from the Catholic Church's longstanding commitment to private property and freedom of contract. Instead, His Holiness recognizes that such values, according to Catholic social teaching, must be tempered by concern for the common good, a recognition that reasonable governance is needed to attend to unjust distributions of wealth and income, that poverty in particular must be mitigated, and that God's creation must not be abused. See, e.g., Thomas J. Molony, Charity, Truth, and Corporate Governance, 56 LOY. L. REv. 825, 829-39 (2010) (successive Popes have "affirmed that private property is a natural right, but ... emphasize more and more that its use may be limited to the extent required for the common good").

18. E.g., Int'L Renewable Energy Agency, Perspectives for the Energy Transition: INVESTMENT NEEDS FOR A LOW-CARBON ENERGY SYSTEM 12 (2016) (finding that massive investment in low-carbon energy could expand global GDP by $\$ 19$ trillion); Zhang Zhixin \& Li Yab, The Impact of Carbon Tax on Economic Growth in China, 5 ENERGY PROCEDIA 1757, 1760-61 (2011) (finding that carbon tax in China would foster growth in some developed provinces and harm growth in other provinces more dependent on extractive activities, but proceeds from carbon tax could mitigate impact in losing provinces by funding infrastructure and human capital investments).

19. RAMIREZ, supra note 15 , at $186-95$.

20. While the learning with respect to the pernicious impact of inequality on law and beyond is expanding rapidly, Pope Francis leads the way in highlighting that the distribution of losses and gains from global warming mimics the distribution of gains and losses from the Great Financial Crisis. The essential problem involves the use of power by a small number of elites to garner windfall profits at great expense to society generally. See RAMIREZ, supra note 15, at xiv (stating the financial crisis makes no sense "except for the raw profitability the risk gorging generated (over the short term, at least), and the distribution of the risk-generated profits to the most economically and politically powerful within our society, at the expense of the most disempowered"). 
will therefore conclude that the recent teachings of Pope Francis (and the Catholic Church) on the topics of social justice and the environment are fully consistent with the most robust systems of capitalism in the world today as well as with traditional economic thinking, going as far back as Adam Smith. ${ }^{21}$ Therefore, legal policymakers (including all branches and agencies of the government) should work to impound the core elements of these teachings to the maximum extent possible to create the most robust and sustainable capitalism possible. ${ }^{22}$

In sum, the Pope's teachings are economically sound, and this supports the moral and spiritual dimensions of His Holiness's teachings. More specifically, this Article concludes that the moral and spiritual dimensions of the teachings of Pope Francis on the global economy and the environment rest upon a strong foundation of economic science. The Pope may not be an expert in market theory, and may raise troubling questions about the essential amorality of market transactions, but His Holiness applies the best learning available from all disciplines and traditional Church teachings to spotlight issues that urgently require the attention of governing elites and that, thus far, fester as profound threats to human well-being and capitalism itself. Simply stated, the Pope is acting as an influential, global, and farsighted spiritual leader.

21. AdAm Smith, The WeAlth of NATiONS 83 (Prometheus Books 1991) (1776) ("No society can surely be flourishing and happy, of which the far greater part of the members are poor and miserable."). Smith recognized that elites could not be counted on to govern in the long-term interest of all as a matter of natural inclination. Id. at 137, 151 (stating that "[p]eople of the same trade seldom meet together, even for merriment and diversion, but the conversation ends in a conspiracy against the public, or in some contrivance to raise prices" and "[w]hen the regulation . . . is in favour of the workmen, it is always just and equitable; but it is sometimes otherwise when in favour of the masters"). Further, Smith fully recognized the need for robust public investment in infrastructure (including mass education for all) as a means for addressing market failures arising from public versus private benefits. $I d$. at 473 (stating that government is duty bound to provide "public institutions" and "public works" that are "in the highest degree advantageous to a great society" but are not profitable to any individual economic actor because of diffusion of benefits). Smith also posited that "every successive generation" held an "equal right to earth." 1 ADAM SMITH, AN INQUIRY INTO THE NATURE AND CAUSES OF THE WEALTH OF NATIONS 384 (Oxford Univ. ed. 1976).

22. In particular, the United States Supreme Court seems clueless with respect to the now manifest dangers of high economic inequality. Instead, the Court seemingly stretches again and again to uphold the power of elites, particularly corporate elites. E.g., ERWIN CHEMERINSKY, THE CASE AGAINST THE SUPREME COURT 294 (2014) ("The Court has, throughout history, largely ruled in favor of the elites, and especially in favor of the interests of business. Given the backgrounds of the justices - not just these, but those throughout American history—is this any surprise?"). Even beyond the courts, lawmakers and regulators should seek to reduce unnecessary vestiges of economic inequality, such as race, wherever possible. See, e.g., Kristin Johnson et al., Diversifying to Mitigate Risk: Can Dodd-Frank Section 342 Help Stabilize the Financial Sector?, 73 WASH. \& LEE L. REV. 1795 , 1867-68 (2016) (urging financial regulators to use congressional authority to aggressively diversify the financial sector). 


\section{THE TEACHINGS OF PoPe Francis ON UNFETTERED CAPITALISM}

Pope Francis's recent statements on the structure of the global economy essentially rest upon three basic premises of social justice teaching, which he applies to the present economic challenges facing humanity ${ }^{23}$ First, His Holiness posits that the global economy leaves too many humans on the economic margins, wallowing in poverty, while the conspicuous consumption of those on the very high-end of the economic hierarchy enjoy unearned privileges that harm the common welfare of humanity. ${ }^{24}$ Second, even if poverty did not exist, there is a spiritual vacancy at the heart of a global economy that seemingly puts economic considerations and conspicuous consumption ahead of human needs, particularly insofar as the environment is concerned. ${ }^{25}$ Third, Pope Francis views these issues as proper for collective action; ${ }^{26}$ indeed, he suggests

\footnotetext{
23. According to Professor Molony:

The Compendium of the Social Doctrine of the Church identifies the dignity of the human person, the common good, subsidiarity, and solidarity as the four fundamental principles of Catholic Social Thought. Although the explanation of these principles has evolved over time as new circumstances have arisen, the principles themselves are constant. They represent a unified framework to be applied collectively, and it is inappropriate to apply one or more principles to the exclusion of others. This is not to say, however, that each principle is given equal weight. Dignity of the human person is the foundational principle from which the other principles derive.
}

Molony, supra note 17, at 829-30 (citing PONTIFICAL COUNCIL FOR Justice AND PeAce, COMPENDIUM OF THE SOCIAL DOCTRINE OF THE CHURCH 160 (2004)).

24. Pope Francis, Address to the General Audience at Saint Peter's Square (June 5, 2013), https://w2.vatican.va/content/francesco/en/audiences/2013/documents/papa-

francesco_20130605_udienza-generale.html [https://perma.cc/R9EY-A5CH] (“[M]en and women are sacrificed to the idols of profit and consumption: it is the 'culture of waste'. If a computer breaks it is a tragedy, but poverty, the needs and dramas of so many people end up being considered normal.").

25. Recently, the Pope stated:

As individuals, we have grown comfortable with certain lifestyles shaped by a distorted culture of prosperity and a "disordered desire to consume more than what is really necessary", and we are participants in a system that "has imposed the mentality of profit at any price, with no concern for social exclusion or the destruction of nature." Let us repent of the harm we are doing to our common home.

Pope Francis, Show Mercy to our Common Home: Pope's Message for the World Day of Prayer for the Care of Creation (Sept. 1, 2016), https://press.vatican.va/content/salastampa/en/bollettino/ pubblico/2016/09/01/160901b.html [https://perma.cc/2S9D-X4R4]. See also Pope Francis, Homily of His Holiness Pope Francis: Solemnity of the Nativity of the Lord (Dec. 24, 2015), https://w2.vatican.va/content/francesco/en/homilies/2015/documents/papa-francesco_20151224 omelia-natale.html [https://perma.cc/CSH9-UQUW] ("In a society so often intoxicated by consumerism and hedonism, wealth and extravagance, appearances and narcissism, this Child calls us to act soberly, in other words, in a way that is simple, balanced, consistent, capable of seeing and doing what is essential.").

26. Thus, for example, the Pope communicated a broad vision of the duties of our elected representatives in his appearance before a Joint Session of Congress:

Your own responsibility as members of Congress is to enable this country, by your legislative activity, to grow as a nation. You are the face of its people, their representatives. You are called to defend and preserve the dignity of your fellow citizens in the tireless and 
[Vol. 40:1229

strengthening global governance to address these issues. ${ }^{27}$ This part of this Article will seek to distill the most important lessons the Pope offers to address contemporary economic challenges while also showing that Pope Francis stands firmly on a foundation of longstanding Catholic teaching on social justice.

The apostolic exhortation, Evangelii Gadium, ${ }^{28}$ constitutes Pope Francis's most important statement on the topic of social justice and capitalism. His teachings apply longstanding Catholic thought to the contemporary global economy and are also consistent with a range of actual practices in nations with superior social justice outcomes. For example, His Holiness emphasizes the problems of high inequality:

$[U] n t i l$ exclusion and inequality in society and between peoples are reversed, it will be impossible to eliminate violence. The poor and the poorer peoples are accused of violence, yet without equal opportunities the different forms of aggression and conflict will find a fertile terrain for growth and eventually explode. When a society - whether local, national or global —is willing to leave a part of itself on the fringes, no political programmes or resources spent on law enforcement or surveillance systems can indefinitely guarantee tranquility. This is not the case simply because inequality provokes a

demanding pursuit of the common good, for this is the chief aim of all politics. A political society endures when it seeks, as a vocation, to satisfy common needs by stimulating the growth of all its members, especially those in situations of greater vulnerability or risk.

Pope Francis, Address of the Holy Father: Visit to the Joint Session of the United States Congress (Sept. 24, 2015), https://w2.vatican.va/content/francesco/en/speeches/2015/september/documents/ papa-francesco_20150924_usa-us-congress.html [https://perma.cc/S6FN-L67A].

27. Pope Francis, Encyclical Letter, Laudato si': On Care for Our Common Home para. 175 (2015), http://w2.vatican.va/content/francesco/en/encyclicals/documents/papa-francesco_20150524 enciclica-laudato-si.html [https://perma.cc/ZV4H-VAXR] [hereinafter Pope Francis, Laudato si'] (" $[I]$ t is essential to devise stronger and more efficiently organized international institutions, with functionaries who are appointed fairly by agreement among national governments, and empowered to impose sanctions."). A focus on the need for strengthening global institutions (but calling for such measures short of any world government) follows the teachings of a long line of papal statements. John M. Breen, Love, Truth, and the Economy: A Reflection on Benedict XVI's Caritas in Veritate, 33 HARV. J.L. \& PUB. POL'Y 987, 1025-29 (2010) (quoting Pope Benedict XVI regarding the Great Financial Crisis: "[T]here is a strongly felt need, even in the midst of a global recession, for a reform of the United Nations Organisation [sic], and likewise of economic institutions and international finance, so that the concept of the family of nations can acquire real teeth."). As Professor Breen explains, any such international institutions would be subject to long-standing principles of subsidiarity under Catholic social teaching. Subsidiarity requires that all government policies be implemented at the most local level possible given the scope of the problem and the need for efficacious solutions. Id. at 1027-28 (quoting Pope Benedict XVI, Encyclical Letter, Caritas in Veritate para. 57 (June 29, 2009) and Pope Pius XI, Encyclical Letter, Quadragesimo anno para. 39 (May 15, 1931)).

28. See generally Pope Francis, Apostolic Exhortation, Evangelii gaudium para. 190 (2013) http://w2.vatican.va/content/francesco/en/apost_exhortations/documents/papa-francesco_ esortazione-ap_20131124_evangelii-gaudium.html [https://perma.cc/D465-X45L] [hereinafter Pope Francis, Evangelii Gaudium]. 
violent reaction from those excluded from the system, but because the socioeconomic system is unjust at its root. ${ }^{29}$

One need not look beyond the United States for validation of the Pope's concern. ${ }^{30}$ Not only is the U.S. more violent than other developed nations but it also suffers from very high economic inequality. ${ }^{31}$ In fact, studies demonstrate a link between homicide rates and inequality, with the U.S. leading the trend. ${ }^{32}$

Inequality also negatively affects life expectancy and infant mortality. ${ }^{33}$ Pope Francis recognizes the impact of high economic inequality on life:

Just as the commandment "Thou shalt not kill" sets a clear limit in order to safeguard the value of human life, today we also have to say "thou shalt not" to an economy of exclusion and inequality. Such an economy kills .... Today everything comes under the laws of competition and the survival of the fittest, where the powerful feed upon the powerless. As a consequence, masses of people find themselves excluded and marginalized[.] $]^{34}$

Given the dramatic differences between developed nations on basic indicia of social well-being such as life expectancy and infant mortality, high inequality today is robbing humanity of untold years of life. ${ }^{35}$ Perhaps even more disturbing, within certain societies disparities at the extremes of socioeconomic hierarchies amount to shocking injustices-in the U.S. sixteen-year-old African Americans in the nation's poorest areas can expect to live twenty-eight years less than sixteen-year-old wealthy whites. ${ }^{36}$

Many may believe that technology and scientific advances can mitigate the threats discussed above, and history does indeed suggest that

29. Id. para. 59. The Church spoke out long ago against unjust and undue compensation for elites, such as CEOs, at the expense of disempowered workers. Vinnie Rotondaro, Is Exorbinate CEO Pay a Form of Tyranny? Thomas Aquinas Thinks So, NAT. CATH. ReP. (Mar 16, 2015), https://www.ncronline.org/news/people/exorbitant-ceo-pay-form-tyranny-thomas-aquinas-thinks-so [https://perma.cc/PFU8-C85A] (quoting Pope Pius XI, Pope John XXIII, Pope John Paul II, and St. Thomas Aquinas).

30. Chris Kirk, The U.S. Is Far More Violent Than Other Rich Countries, SLATE: THE SLATEST (Oct. 2, 2015), http://www.slate.com/blogs/the_slatest/2015/10/02/is_the_u_s_more_violent_than other_countries_what_the_data_shows.html [https://perma.cc/KV5K-EV8K] ("The U.S. really is far more violent than other advanced countries....").

31. Erik Sherman, America is the Richest, and Most Unequal, Country, ForTunE (Sept. 30, 2015) http://fortune.com/2015/09/30/america-wealth-inequality/ [https://perma.cc/6BUU-SH4J].

32. See, e.g., Richard Wilkinson \& Kate Pickett, The Spirit LeVel: Why Greater EQUALITY MAKES SOCIETIES STRONGER (2011).

33. Id. at figs.6.3, 6.4.

34. Pope Francis, Evangelii Gaudium, supra note 28, para. 53.

35. WILKINSON \& PICKETT, supra note 32, at figs.6.3, 6.4.

36. Id. at 84 . 
technological advances can in fact advance the human condition. ${ }^{37}$ The unequal distribution of the benefits of technological advances, however, highlights His Holiness's point with respect to the condition of billions of human beings:

In our time humanity is experiencing a turning-point in its history, as we can see from the advances being made in so many fields. We can only praise the steps being taken to improve people's welfare in areas such as health care, education and communications. At the same time we have to remember that the majority of our contemporaries are barely living from day to day, with dire consequences. A number of diseases are spreading. The hearts of many people are gripped by fear and desperation, even in the so-called rich countries. The joy of living frequently fades, lack of respect for others and violence are on the rise, and inequality is increasingly evident. It is a struggle to live and, often, to live with precious little dignity. ${ }^{38}$

Socioeconomic status still poses a major risk factor in human health and well-being; simply occupying a place on the lower stratum of global society robs many humans of years of life notwithstanding scientific advances. ${ }^{39}$ Furthermore, the number of human beings living in deep poverty amidst a global culture of riches remains stubbornly high: "In 2013, the year of the latest comprehensive data on global poverty, 767 million people are estimated to have been living below the international poverty line of US $\$ 1.90$ per person per day." 40

His Holiness also raises concerns about another contemporary problem regarding the power of those at the top of the economic hierarchy, particularly corporate and financial elites:

Debt and the accumulation of interest also make it difficult for countries to realize the potential of their own economies and keep

37. One well-reported study found that global life expectancy increased by six years between 1990 and 2013. See Gautam Naik, Global Life Expectancy Increases by About Six Years, WALL ST. J. (Dec. 18, 2014), https://www.wsj.com/articles/global-life-expectancy-increases-by-about-six-years1418861100 [https://perma.cc/QBM6-R6EZ].

38. Pope Francis, Evangelii Gaudium, supra note 28, para. 52.

39. Silvia Stringhini et al., Socioeconomic Status and the $25 \times 25$ Risk Factors as Determinants of Premature Mortality: A Multicohort Study and Meta-Analysis of 1.7 Million Men and Women, 389 LANCET 1229, 1232-35 (2017) ("Low socioeconomic status was associated with 2.1 year reduction in in life expectancy between ages 40 and 85 years, [while] the corresponding years-of-life-lost were 0.5 for high alcohol intake, 0.7 for obesity, 3.9 for diabetes, 1.6 for hypertension, 2.4 for physical inactivity, and 4.8 for current smoking.").

40. WORLD BANK, POVERTY AND SHARED PROSPERITY 2016: TAKING ON INEQUALITY 3 (2016). While significant strides in poverty reduction occurred in recent years, hardly any of the reduction occurred in Sub-Saharan Africa where forty-one percent of the population lives in deep poverty. Id. at 4. Further, despite progress on deep poverty, illiteracy still takes a significant toll on human development, with 780 million adults worldwide still suffering from illiteracy. Id. at 2. 
citizens from enjoying their real purchasing power. To all this we can add widespread corruption and self-serving tax evasion, which have taken on worldwide dimensions. The thirst for power and possessions knows no limits. In this system, which tends to devour everything which stands in the way of increased profits, whatever is fragile, like the environment, is defenseless before the interests of a deified market, which become the only rule. ${ }^{41}$

After the Great Financial Crisis of 2007-2009, the threats posed by excessive debt and the unbridled power of financial elites cried out for attention. ${ }^{42}$ Many powerful CEOs at the center of that crisis in capitalism garnered huge payouts for their failures, amounting to obscene windfalls ultimately funded by taxpayer bailouts. ${ }^{43}$

In terms of corruption, not a single CEO in the U.S. suffered a criminal indictment, nor did the banks they led into a frenzy of fraud suffer any regulatory sanction despite longstanding anti-fraud laws in the financial sector. $^{44}$

Pope Francis astutely sums up today's basic economic realities:

Today's economic mechanisms promote inordinate consumption, yet it is evident that unbridled consumerism combined with inequality proves doubly damaging to the social fabric. Inequality eventually engenders a violence which recourse to arms cannot and never will be able to resolve. It serves only to offer false hopes to those clamouring for heightened security, even though nowadays we know that weapons and violence, rather than providing solutions, create new and more serious conflicts. Some simply content themselves with blaming the poor and the poorer countries themselves for their troubles; indulging in unwarranted generalizations, they claim that the solution is an "education" that would tranquilize them, making them tame and harmless. All this becomes even more exasperating for the marginalized in the light of the widespread and deeply rooted corruption found in many countries - in their governments,

41. Pope Francis, Evangelii Gaudium, supra note 28, para. 56.

42. RAMIREZ, supra note 15 , at xiii-xiv (showing that excessive debt and predatory lending triggered the financial crisis and stating that the crisis only made sense by following the money trail of illusory profits to the "most economically and politically powerful within our society, [profiting] at the expense of the most disempowered").

43. $I d$. at 192 ("In early 2011, the government apparently terminated its criminal inquiry against Countrywide Financial CEO Angelo Mozilo. Mozilo raked in \$521 million from 2000 to 2008, even as he crashed his firm through predatory loans that he himself recognized as toxic and poisonous.").

44. Mary Kreiner RamireZ \& Steven A. Ramirez, The CaSe For the Corporate Death PENALTY 1-27 (2016) (reviewing evidence of fraud and the many laws designed to punish fraud and concluding that "a new and unprecedented lawlessness emerged at the apex of American capitalism"). 
businesses and institutions - whatever the political ideology of their leaders. ${ }^{45}$

In other words, the current economic structure of capitalism troubles His Holiness on a spiritual level because it seemingly wastes many resources through excessive consumption and corrupt legal institutions while disempowering too many, a situation ripe for violence.

In the encyclical, Laudato si, ${ }^{46}$ His Holiness extends the critique of runaway consumption and greed to our common home, Earth:

I urgently appeal, then, for a new dialogue about how we are shaping the future of our planet. We need a conversation which includes everyone, since the environmental challenge we are undergoing, and its human roots, concern and affect us all. The worldwide ecological movement has already made considerable progress and led to the establishment of numerous organizations committed to raising awareness of these challenges. Regrettably, many efforts to seek concrete solutions to the environmental crisis have proved ineffective, not only because of powerful opposition but also because of a more general lack of interest. Obstructionist attitudes, even on the part of believers, can range from denial of the problem to indifference, nonchalant resignation or blind confidence in technical solutions. We require a new and universal solidarity. ${ }^{47}$

Pope Francis decries treating the Earth as just another thing to consume and throw away (like excluded persons): "The earth, our home, is beginning to look more and more like an immense pile of filth." ${ }^{48}$ Indeed, His Holiness subsequently termed environmental destruction a "sin against God." 49

Yet, His Holiness reserves particular concern for climate change:

A very solid scientific consensus indicates that we are presently witnessing a disturbing warming of the climatic system. In recent decades this warming has been accompanied by a constant rise in the sea level and, it would appear, by an increase of extreme weather events, even if a scientifically determinable cause cannot be assigned to each particular phenomenon. Humanity is called to recognize the

45. Pope Francis, Evangelii Gaudium, supra note 28, para. 60.

46. Pope Francis, Laudato si', supra note 27.

47. Id. para. 14 .

48. Id. para. 21.

49. Pope Francis, Message of His Holiness Pope Francis for the Celebration of the World Day of Prayer for the Care of Creation: Show Mercy to Our Common Home (Sept. 1, 2016) (quoting Ecumenical Patriarch Bartholomew I of Constantinople, Address in Santa Barbara, California (Nov. 8, 1997)), https://w2.vatican.va/content/francesco/en/messages/pont-messages/2016/documents/ papa-francesco_20160901_messaggio-giornata-cura-creato.html\#_ftnref2 [https://perma.cc/7J3MTQHG]. 
need for changes of lifestyle, production and consumption, in order to combat this warming or at least the human causes which produce or aggravate it. ${ }^{50}$

His Holiness relates much of the climate problem to fossil fuels: "The problem is aggravated by a model of development based on the intensive use of fossil fuels, which is at the heart of the worldwide energy system." He further states that climate change "represents one of the principal challenges facing humanity in our day. Its worst impact will probably be felt by developing countries in coming decades. Many of the poor live in areas particularly affected by phenomena related to warming . ..."

Environmental scholars and scientists that studied the evidence relating to climate change and its causes generally shared the Pope's conclusion regarding climate change prior to the publication of Laudato $s i{ }^{53}$ The same holds true with respect to the consequences of climate change, where the scientific community has reached consensus on the

50. Pope Francis, Laudato si', supra note 27, para. 23.

51. Id.

52. Id. para. 25 .

53. Perhaps the most influential scientific body to study climate change is the Intergovernmental Panel on Climate Change (IPCC), which issued an overview of the evidence in 2014. "The IPCC's overview is its fifth since $1990 \ldots$. . Scientists have become ever more certain that human activity is to blame for climate change: about $95 \%$ certain, in fact (the first report said climate change was as likely as not a product of natural variation)." Of Warming and Warnings, ECONOMIST (Nov. 3, 2014), http://www.economist.com/news/science-and-technology/21630639-most-comprehensive-climatereport-yet-issues-its-shots-across-bow-warming-and [https://perma.cc/6PC9-2SPC] (citing IPCC, Climate Change 2014: Synthesis RePORT 4 (2014)) (“Anthropogenic greenhouse gas emissions have increased since the pre-industrial era . . . and are now higher than ever. Their effects, together with those of other anthropogenic drivers ... are extremely likely to have been the dominant cause of the observed warming since the mid-20th century."). Even before the fifth IPCC report, the national science academies of advanced nations (Brazil, Canada, China, France, Germany, India, Italy, Japan, Russia, the United Kingdom, and the United States) accepted the earlier findings by the IPCC that human activity likely caused global warming:

$[T]$ here is now strong evidence that significant global warming is occurring. The evidence comes from direct measurements of rising surface air temperatures and subsurface ocean temperatures and from phenomena such as increases in average global sea levels, retreating glaciers, and changes to many physical and biological systems. It is likely that most of the warming in recent decades can be attributed to human activities.

Joint Sci. Acads.' Statement: Glob. Response to Climate Change (June 7, 2005), http://nationalacademies.org/onpi/06072005.pdf [https://perma.cc/SEM2-JJ47]; see also Joint Sci. Acads.' Statement: Climate Change Adaptation and the Transition to a Low Carbon Soc'y (June 2008), http://www.scj.go.jp/ja/info/kohyo/pdf/kohyo-20-s7.pdf [https://perma.cc/ND9E-EK7Z] (same group, with the addition of Mexico and South Africa, renewing call for action to address climate change threats and stating that "the rate and scale of climate change means there is no time for complacency"). In 2007, the IPCC shared the Nobel Peace Prize for "their efforts to build up and disseminate greater knowledge about man-made climate change, and to lay the foundations for the measures that are needed to counteract such change." Press Release, The Norwegian Nobel Committee, The Nobel Peace Prize for 2007 (Oct. 12, 2007), http://www.nobelprize.org/ nobel_prizes/peace/laureates/2007/press.html [https:/perma.cc/G4KW-6XR7]. 
dangers posed by global warming. ${ }^{54}$ There is also broad consensus regarding concerns that the world's poor will disproportionately suffer from global warming. ${ }^{55}$

Since the publication of Laudato si', the great weight of commentary agreed with the general position of Pope Francis. ${ }^{56}$ Indeed, if anything the

54. While thus far the impact of global warming on human welfare appears to be moderate, the future is less benign:

Impacts from recent climate-related extremes, such as heat waves, droughts, floods, cyclones, and wildfires, reveal significant vulnerability and exposure of some ecosystems and many human systems to current climate variability (very high confidence). Impacts of such climate-related extremes include alteration of ecosystems, disruption of food production and water supply, damage to infrastructure and settlements, morbidity and mortality, and consequences for mental health and human well-being. For countries at all levels of development, these impacts are consistent with a significant lack of preparedness for current climate variability in some sectors.

IPCC, Climate Change 2014: ImPacts, Adaptation, And Vulnerability: Summary for POLICYMAKERS 6 (2014).

55. According to the IPCC:

People who are socially, economically, culturally, politically, institutionally, or otherwise marginalized are especially vulnerable to climate change and also to some adaptation and mitigation responses (medium evidence, high agreement). This heightened vulnerability is rarely due to a single cause. Rather, it is the product of intersecting social processes that result in inequalities in socioeconomic status and income, as well as in exposure.

Id.

56. E.g., Mary Evelyn Tucker \& John Grim, Integrating Ecology and Justice: The Papal Encyclical, 91 Q. REV. BIO. 261, 264 (2016) ("Indeed, many scientists and ecologists have been keen to draw on the message of the Encyclical and are impressed by its solid scientific grounding."); Marcelo Sánchez Sorondo \& Veerabhadran Ramanathan, Pursuit of Integral Ecology, 352 SCIENCE 747, 747 (2016) (“Pope Francis' effort to unite science, policy, and religion toward an integral ecology approach is just a start. We hope that other religions and moral and political leaders will join this new synergy and nudge society toward equitable solutions to ecological and social justice . . . ."); John Nagle, Opinion, Pope Francis was Right on Climate Change, WASH. POST (Jan. 7, 2016), https://www.washingtonpost.com/news/in-theory/wp/2016/01/07/pope-francis-was-right-on-climatechange/?utm_term=.f1456ff90880 [https://perma.cc/AL3W-3MHZ] ("To find solutions for climate change and other environmental challenges, we need to focus on the morality of our actions, including questions of fairness and obligation."); Gautam Naik, Scientists Back Pope Francis on Global Warming, WALL ST. J. (June 18, 2015), https://www.wsj.com/articles/scientists-back-pope-francison-global-warming-1434648362 [https://perma.cc/F76E-3HCA] (quoting academic experts stating that the Pope's conclusions enjoy wide acceptance in the scientific community); Jenny Stalevich \& Jennifer Luna, Pope Offers Simple Message to South Florida: Less is More, Miami Herald (June 18, 2015), http://www.miamiherald.com/news/local/environment/article24921451.html\#storylink=cpy [https://perma.cc/67CJ-R3X3] ("Despite widespread acceptance by scientists, both Jeb Bush and Marco Rubio - two hometown Republican presidential contenders with ties to the church-also have expressed skepticism that humans have propelled climate change. And Florida's Republican leadership has done little to plan for changes."); Rev. John I. Jenkins, Opinion, The Pope's Challenge on Global Warming, CHI. TRIB. (June 17, 2015), http://www.chicagotribune.com/news/opinion/ commentary/ct-pope-francis-climate-change-perspec-0618-20150617-story.html [https://perma.cc/ UE77-HUMY] ("University of Notre Dame scientists annually rank 180 of the world's nations on their vulnerability to climate change. Those who reside in the poorest countries are 10 times more likely to be hurt by a climate disaster than those in wealthy nations."). But see Editorial, The Pope's Global Warming Encyclical: Don't Be Misled, INV. Bus. DAILY (June 16, 2015), http://www.investors.com/politics/editorials/climate-change-not-part-of-popes-calling/ 
scientific consensus supporting the Pope's position is stronger than ever and is now "virtually unanimous," at least among climate scientists. ${ }^{57}$ The key point from an economic perspective is that like the pernicious inequality hobbling our global economy, climate change reflects the very same attitude of consumerism run amok and insatiable materialism among governing elites. ${ }^{58}$

Pope Francis also offers real solutions to the problems identified in Evangelii Gaudium and Laudato si'. For example, he calls for more international enforcement of environmental protections: "Enforceable international agreements are urgently needed, since local authorities are not always capable of effective intervention. Relations between states must be respectful of each other's sovereignty, but must also lay down mutually agreed means of averting regional disasters which would eventually affect everyone." ${ }^{, 59}$ Indeed, the Pope suggests: "What is needed,

[https://perma.cc/A5WZ-5YCM] ("Pope Francis' job is spreading his faith in God, not abandoning reason and placing his faith instead in a 'scientific consensus' that doesn't exist—which even if it did, it would be wrong.").

57. James Lawrence Powell, Climate Scientists Virtually Unanimous: Anthropogenic Global Warming Is True, 35 Bull. SCI., TECH. \& Soc. 121, 121 (2015) (“During 2013 and 2014, only 4 of 69,406 authors of peer-reviewed articles on global warming, $0.0058 \%$ or 1 in 17,352 , rejected AGW. Thus, the consensus on AGW among publishing scientists is above $99.99 \%$, verging on unanimity."). Among the broader scientific community, a powerful consensus recently emerged in full support of the consensus present among climate scientists. As The Bulletin of Atomic Scientists recently stated:

The continued warming of the world measured in 2016 underscores one clear fact: Nothing is fundamentally amiss with the scientific understanding of climate physics. The burning of fossil fuels adds carbon dioxide to the atmosphere; carbon dioxide is a greenhouse gas, inhibiting the radiation of heat into space. The relationship between increased atmospheric carbon dioxide levels and increased terrestrial temperature has been researched for decades, and national science academies around the world agree: Human activity is the primary cause of climate change, and unless carbon dioxide emissions are dramatically reduced, global warming will threaten the future of humanity.

Press Release, Bull. of Atom. Scientists, It is Two and a Half Minutes to Midnight: 2017 Doomsday Clock Statement Science and Security Board Bulletin of the Atomic Scientists (Jan. 26, 2017), § 4, https://thebulletin.org/sites/default/files/Final\%202017\%20Clock\%20Statement.pdf [https://perma.cc/F8JB-TN9L].

Founded in 1945 by University of Chicago scientists who had helped develop the first atomic weapons in the Manhattan Project, the Bulletin of the Atomic Scientists created the Doomsday Clock two years later, using the imagery of apocalypse (midnight) and the contemporary idiom of nuclear explosion (countdown to zero) to convey threats to humanity and the planet. The decision to move (or to leave in place) the minute hand of the Doomsday Clock is made every year by the Bulletin's Science and Security Board in consultation with its Board of Sponsors, which includes 15 Nobel laureates. The Clock has become a universally recognized indicator of the world's vulnerability to catastrophe from nuclear weapons, climate change, and new technologies emerging in other domains.

Id. $\S 1$. Today the doomsday clock is closer to midnight than any time since the 1950 s. See id. $§ 16$. 58. See Pope Francis, Laudato Si', supra note 27, paras. 34, 48, 50, 56, 109, 184, 193.

59. Id. para. 173. His Holiness certainly does not argue for a world government. See id. Nevertheless, the Pope recognizes the profound impact of more global problems - such as inequality and the environment - to outstrip the ability of nation states to craft efficacious political solutions. See 
in effect, is an agreement on systems of governance for the whole range of so-called 'global commons." "60 This international arrangement must, at the least, apportion environmental costs on those causing the environmental damage - presumably some scheme for carbon taxation. ${ }^{61}$ Such a carbon tax could fund massive public investment worldwide in "green" technology and "green" economic development to alleviate global poverty. ${ }^{62}$

Most fundamentally, Pope Francis continues to urge a preferential option for the poor. ${ }^{63}$ "We are called to find Christ in [the poor], to lend our voice to their causes, but also to be their friends, to listen to them, to speak for them and to embrace the mysterious wisdom which God wishes to share with us through them." "Ad Adressing the causes of poverty "cannot be delayed, not only for the pragmatic reason of its urgency for the good order of society, but because society needs to be cured of a sickness which is weakening and frustrating it, and which can only lead to new crises." 65 Further, "[a]s long as the problems of the poor are not radically resolved by rejecting the absolute autonomy of markets and financial speculation and by attacking the structural causes of inequality, no solution will be found for the world's problems ...." ${ }^{96}$ Indeed, according to Pope Francis, "Inequality is the root of social ills." ${ }^{, 67}$ Here, the Pontiff implicitly

$i d$. para. 175 ("The same mindset which stands in the way of making radical decisions to reverse the trend of global warming also stands in the way of achieving the goal of eliminating poverty. A more responsible overall approach is needed to deal with both problems ....").

60. Id. para. 174. Human resources are simply another type of global commons, as is a robust middle class. Strong human resources within a given economy allow businesses to hire more productive workers, and a robust middle class furnishes demand for innovative products. See RAMIREZ, supra note 15, at 218.

61. Pope Francis, Laudato Si', supra note 27, para. 167 (applauding the 1972 Stockholm Declaration for enshrining "the obligation of those who cause pollution to assume its costs"). Pope Francis expands on this notion: "[B]usinesses profit by ... paying only a fraction of the costs involved. Yet only when the economic and social costs of using up shared environmental resources are recognized with transparency and fully borne by those who incur them, not by other peoples or future generations', can those actions be considered ethical." Id. para. 195 (quoting Pope Benedict XVI, Encyclical Letter, Caritas in Veritate (2009), http://w2.vatican.va/content/benedictxvi/en/encyclicals/documents/hf_ben-xvi_enc_20090629_caritas-in-veritate.html [https://perma.cc/5S5X-YBFE]).

62. Benjamin Arki, 5 Ways to Reduce the Drivers of Climate Change, WORLD BANK (Mar. 18, 2015), http://www.worldbank.org/en/news/feature/2015/03/18/5-ways-reduce-drivers-climatechange [https://perma.cc/R5AN-KAVX] (quoting World Bank President Jim Yong Kim regarding policies that would reduce poverty and encourage renewable and low carbon energy use).

63. See Pope Francis, Evangelii Gaudium, supra note 28, para. 195.

64. Id. para. 198.

65. Id. para. 202.

66. Id.

67. Id. 
recognizes that the most disadvantaged among us, axiomatically, are likely the greatest source of future ingenuity. ${ }^{68}$

The Pope's confidence in the potential of human ingenuity seemingly knows no bounds. He is even convinced that human ingenuity will ultimately save the environment. ${ }^{69}$ As Pope Francis stated before the United Nations General Assembly, "Among other things, human genius, well applied, will surely help to meet the grave challenges of ecological deterioration and of exclusion." Pope's key teachings: why waste such vast human potential mired in poverty when the challenges facing humanity desperately require human ingenuity?

No challenge exceeds the urgency of climate change. Recently, the United States repudiated the Paris Climate Change Accord, joining Nicaragua and Syria as the only nations declining to participate in that international agreement intended to contain global warming. ${ }^{71}$ According

68. The Catholic Church has never contested that God endowed human beings with differing capabilities and that as a result people may hold differing claims on resources. See Pope Leo XIII, Rerum Novarum, supra note 8, para. 17 ("There naturally exist among mankind manifold differences of the most important kind; people differ in capacity, skill, health, strength; and unequal fortune is a necessary result of unequal condition. Such unequality [sic] is far from being disadvantageous either to individuals or to the community."). Yet such inequalities must be legitimately earned. Id. para. 20 (stating that the rich "must religiously refrain from cutting down the workmen's earnings, whether by force, by fraud, or by usurious dealing; and with all the greater reason because the laboring man is, as a rule, weak and unprotected, and because his slender means should in proportion to their scantiness be accounted sacred"). There is a difference between earned inequality and inequality based upon privilege, corruption, or other illegitimate advantage. In the U.S. today, for example, the meritocracy looks more mythological than real. See, e.g., RAMIREZ, supra note 15, at 192-93 (showing that many very wealthy and powerful financial elites escaped criminal accountability after the Great Financial Crisis); Id. at 133-37 (recounting the fundamentally uneven playing field prevailing in the United States today and concluding that the any American meritocracy is a myth); Poison Ivy, ECONOMIST (Sept. 21, 2006), http://www.economist.com/node/7945858 [https://perma.cc/3F7K-RWVY] (citing DANIEl GoldEN, THE PRICE OF ADMISSION (2006)) (showing that elite university admissions are pervasively corrupt). Thus, if privilege matters too much it must mean that too much potential is trapped among the disempowered.

69. There are four primary means for dealing with climate change, all of which demand more human ingenuity. First, humanity could rapidly and immediately transition to non-carbon energy sources to slash carbon emissions. Second, humans can enhance efforts to mitigate the effects of climate change by facilitating adaptations to relatively rapid changes in earth's climate. Third, humans can pursue new technologies for the removal of carbon from the atmosphere. Fourth, humans can find ways to influence the climate, for example, through changing earth's reflexivity of solar energy, to reduce the pace of climate change (also known as albedo modification). See NATIONAL RESEARCH Council, Climate Intervention: Reflecting Sunlight to CoOl Earth 1-2 (2015).

70. Pope Francis, Address of the Holy Father, United Nations Headquarters, Meeting with the Members of the General Assembly of the United Nations Organization (Sept. 25, 2015), http://w2.vatican.va/content/francesco/en/speeches/2015/september/documents/papafrancesco_20150925_onu-visita.html [https://perma.cc/RRX7-KURJ].

71. Denise Lu \& Kim Soffen, Only Two Countries Aren't Part of the Paris Climate Agreement. The U.S. Will Be the Third., WASH. POST (June 1, 2017), https://www.washingtonpost.com/graphics/ world/paris-climate-agreement-withdrawal/?utm_term $=.58 \mathrm{bf} 94 \mathrm{~b} 0 \mathrm{f} 743$. Remarkably, most business 
[Vol. 40:1229

to the Center for Responsive Politics the oil, gas, and coal industries provide a key source of cash funding for the politics of climate change denial. ${ }^{72}$ Further, in a study of the twenty-two senators pushing hardest for withdrawal from the Paris Accord, the Center found that those same industries had bankrolled the campaigns of those senators to the tune of $\$ 10,694,284 .{ }^{73}$ Climate change denial represents the triumph of big money politics and "think tanks" over the welfare of humanity and therefore warrants the attention of spiritual leaders such as Pope Francis. ${ }^{74}$

While Pope Francis's teachings stir much controversy, the controversy ought to focus on Catholic teaching as a whole, as His Holiness simply applies those teachings to contemporary problems. Pope Leo XIII spoke of the misery of the working classes in 1891, and called on capitalists to pay laborers a living wage, and to address festering tension between laissez-faire enthusiasts on one hand and Marxists on the other. ${ }^{75}$ Pope Leo also called for collective action-that is, government intervention into the economy - to resolve the pain of the working class. ${ }^{76}$ Here, longstanding Catholic doctrine holds that societies should be governed in accordance with a preferential option for the poor because they likely are disadvantaged in seeking collective action to defend their rights. $^{77}$

interests favored remaining in the Paris Accord. Andrew Winston, U.S. Business Leaders Want to Stay in the Paris Climate Accord, HARV. Bus. Rev., May 31, 2017, https://hbr.org/2017/05/u-s-businessleaders-want-to-stay-in-the-paris-climate-accord.

72. Rachel Wilson, Oil, Gas and Coal Interests Filling Donald Trump's 'Swamp' with Cash, CTR. FOR PUB. INTEGRITY (May 2, 2017), https://www.publicintegrity.org/2017/05/02/20848/oil-gasand-coal-interests-filling-donald-trump-s-swamp-cash.

73. Tom McCarthy \& Lauren Gambino, The Republicans Who Urged Trump to Pull Out of Paris Deal Are Big Oil Darlings, GuARDIAN (June 1, 2017), https://www.theguardian.com/usnews/2017/jun/01/republican-senators-paris-climate-deal-energy-donations.

74. See, e,g., Jane Meyer, In The Withdrawal From The Paris Climate Agreement, The Koch Brothers' Campaign Becomes Overt, New YORKER (June 5, 2017), http://www.newyorker.com/ news/news-desk/in-the-withdrawal-from-the-paris-climate-agreement-the-koch-brothers-campaignbecomes-overt ("If there was any lingering doubt that a tiny clique of fossil-fuel barons has captured America's energy and environmental policies, it was dispelled last week, when the Trump Administration withdrew from the Paris climate accord.").

75. Pope Leo XIII, Rerum Novarum, supra note 8, para. 45 ("[T] natural justice more imperious and ancient than any bargain between man and man, namely, that wages ought not to be insufficient to support a frugal and well-behaved wage-earner."). The definition of a living wage includes that which is needed to support a laborer's family and allow the laborer to accumulate savings. $I d$.

76. $I$ d. para. 32 (" $[\mathrm{I}] \mathrm{t}$ lies in the power of a ruler to benefit every class in the State . . . and to promote to the utmost the interests of the poor . . . [T] [Te more that is done for the benefit of the working classes by the general laws of the country, the less need will there be to seek for special means to relieve them.").

77. Twomey, supra note 8, at 327 (quoting Pope John Paul II: "The Church would not be faithful to the Gospel if she were not close to the poor and if she did not defend their rights."). 
Pope Francis clearly attends to the most vexing problems facing humanity in Laudato si' and Evangelii Gaudium. Moreover, His Holiness clearly sees the consequences for human life and well-being at stake in these issues. His application of Catholic social teachings to these vexing problems is tightly tethered to the teachings of other popes going back to the nineteenth century. The next Part of this Article will show that these teachings also comport with economic science.

\section{THE TEACHINGS OF ECONOMICS ON UNFETTERED CAPITALISM}

Pope Francis objects to an "economy of exclusion and inequality"78 and instead argues that "equal opportunities" exclusion and marginalization. ${ }^{80}$ Separate and apart from the compelling moral dimensions of this position, this Part will show that investing in children through educational opportunities, health care, decent housing, and nutrition (in accordance with economic human rights) ${ }^{81}$ costs society nothing while opening opportunities for new ideas that fuel significant gains in macroeconomic growth and, ultimately, human development. ${ }^{82}$ Moreover, it is human ingenuity that constantly expands the capacity of our common home to support life, and therefore building human ingenuity leads to sustainable growth. ${ }^{83}$ In sum, economic growth is all about new ideas, which necessarily puts human welfare front and center. ${ }^{84}$

Robert Solow won the Nobel Prize in Economics in 1987 for showing that economic growth was driven more by technological change than either capital deepening within an economy or adding more labor to an economy. ${ }^{85}$ Ever since, economists have strived to understand the

78. Pope Francis, Evangelii Gaudium, supra note 28, para. 53.

79. Id. para. 59.

80. Id. para. 53.

81. G.A. Res. 217 (III) A, Universal Declaration of Human Rights (Dec. 10, 1948); International Covenant on Economic, Social, and Cultural Rights, Jan. 3, 1976, 993 U.N.T.S. 3.

82. Steven A. Ramirez, Taking Economic Human Rights Seriously After the Debt Crisis, 42 LoY. U. CHI. L.J. 713, 719 (2011) ("Sound human capital formation, unencumbered by privilege or lack thereof, is now identified as central to economic performance."). See also James J. Heckman, China's Human Capital Investment, 16 CHINA ECON. REV. 50, 54 (2005) ("The human capital concept recognizes that human beings are as important, if not more important, than physical capital in creating wealth.").

83. Edward B. Barbier, A Global Green New Deal: Rethinking the Economic ReCOVERY 4 (2010); EBAN S. GoOdSTEIn, ECONOMics AND THE ENVIRONMENT 119-21 (4th ed. 2007). "More than 200 years ago, Thomas Malthus predicted that population growth would outstrip earth's resources. History shows that Malthus simply underestimated human ingenuity." RAMIREZ, supra note 15, at 21 (citing JoSEPH A. SCHUMPETER, THE History OF ECONOMIC ANALYSIS 571 (1954)).

84. Ideas are nonrivalrous in the sense that they retain value no matter how many persons use them. They cannot be consumed. RAMIREZ, supra note 15, at 23-24, 28.

85. Press Release, Nobel Prize, The Sveriges Riksbank Prize in Economic Sciences in Memory of Alfred Nobel 1987 Awarded to Robert M. Solow (Oct. 21, 1987) (“Technological development will 
dynamics of technological change and thus economic growth ${ }^{86}$ Indeed, an entire new branch of macroeconomics exists as a tribute to Solow's essential insight-endogenous growth theory. ${ }^{87}$ Endogenous growth theory seeks to explain macroeconomic growth and its key insight revolves around human ingenuity, innovation, and new ideas. ${ }^{88}$

Obviously, ideas and innovation arise from uniquely human intellectual capabilities. As such, studies of economic growth focus on the role of education, skills attainment, and human capital formation as essential elements of economic growth. ${ }^{89}$ Moreover, because new ideas by definition arise from an essentially "uncharted sea," both wealthy and developing societies must value each human as a potential innovator to maximize aggregate innovation..$^{90}$ Echoing the lessons from Pope Francis, economists recently found that widely dispersed human capital investments in less developed economies paid even higher growth dividends than highly concentrated human capital investments. ${ }^{91}$ Therefore, nations should not only focus on overall investment in human

be the motor for economic growth in the long run. In Solow's model, if continuous technological progress can be assumed, growth in real incomes will be exclusively determined by technological progress.").

86. Indeed, today economists now turn to their understanding differences in macroeconomic performance at the state level. Eric A. Hanushek et al., Knowledge Capital and Aggregate Income Differences: Development Accounting for U.S. States, AM. ECON. J. (forthcoming 2017) (finding that twenty percent to thirty percent of the state variation in per-capita GDP is attributable to human capital differences measured by school attainment and cognitive skills).

87. Paul M. Romer, The Origins of Endogenous Growth, 8 J. ECON. PERSP. 3,13 (1994).

88. "The main engine of growth is the accumulation of human capital — of knowledge — and the main source of differences in living standards among nations is differences in human capital." Robert Lucas, Making a Miracle, 61 ECONOMETRICA 251, 270 (1993).

89. Eric A. Hanushek \& Ludger Woessmann, Education and Economic Growth, in 2 INT'L ENCYCLOPEDIA OF EDUC. 245-52 (2010) (finding strong evidence that cognitive skills-instead of mere years in school-are powerfully related to economic growth in the long term but that poor institutions lead to corruption and not skills attainment). Poor institutions can lead to the corruption of educational funding in favor of the rich. See Era Dabla-Norris \& Mark Gradstein, The Distributional Bias of Public Education: Causes and Consequences 15 (IMF Working Paper No. 04/214, Nov. 2004), https://www.imf.org/external/pubs/ft/wp/2004/wp04214.pdf [https://perma.cc/SV9D-NDNJ] (finding that spending on education is biased towards the rich and that "weak governance leads to intensified rent-seeking over public education funds, increasing inequality, reducing social mobility, and slowing growth").

90. RAmirez, supra note 15, at 24 (citing Joseph A. SCHUMPETER, CAPITAlism, Socialism AND DEMOCRACY 118 (3d ed. 1950)).

91. Nannan Yu et al., Does Inequality in Educational Attainment Matter for China's Economic Growth?, 41 INT'L J. EDUC. DEV. 164 (2015) (finding that dispersal of educational attainment drove higher growth in less developed provinces of China); see also Ampro Castello \& Rafael Domenech, Human Capital Inequality and Economic Growth: Some New Evidence, 112 EcoN. J. C187, C199 (2002) ("In short, these findings indicate that education inequality is associated with lower investment rates and, consequently, lower income growth."). 
capital but also see to it that human capital investments are widely dispersed throughout society to achieve maximum economic inclusivity. ${ }^{92}$

Of course, as Pope Francis recognizes, there is more to human development than education. Health care, in particular, is needed to assure that children can learn and workers can innovate and achieve top productivity. ${ }^{93}$ Empirical evidence shows that "the growth rate of per capita income is strongly and positively influenced by the stock of, and investment in, health human capital after controlling for other variables." ${ }^{4}$ Child healthcare and nutrition pay hefty dividends in the form of enhanced cognition and capabilities. ${ }^{95}$ Again, it appears that widely dispersed public health expenditures drive growth more than private health expenditures by wealthy persons. ${ }^{96}$

Pope Francis's focus on the harmful effects of economic inequality also rests on a solid economic foundation. ${ }^{97}$ One problem with high levels of economic inequality is that it leads to a concentration of wealth in very few hands. ${ }^{98}$ Decades ago, economist Mancur Olson recognized that high

92. Jungsoo Park, Dispersion of Human Capital and Economic Growth, $28 \mathrm{~J}$. MACROECONOMICS 520 (2006) (finding that widely dispersed human capital investment-measured based upon educational attainment - fueled economic growth in ninety-four developed and developing countries for 1960-1995).

93. Gang Chen et al., Health Investment and Economic Output in Regional China, 32 ConTEMP. ECON. POL'Y 261 (2014) (“Using a 29-year (1978-2006) panel of provincial-level data from China, this article investigates the role of health capital in a human capital model of economic output. Robust evidence is found through panel ... that health capital has a significant and positive effect on the Gross Regional Product in China[.]").

94. Kwabena Gyimah-Brempong \& Mark Wilson, Health Human Capital and Economic Growth in Sub-Saharan African and OECD Countries, 44 Q. REV. ECON. FIN. 296 (2004) ("Our estimates suggest that $22 \%$ and $30 \%$ of the transition growth rate of per capita income in Sub-Saharan African and OECD countries respectively, can be attributed to health.").

95. WORLd BANK, World DEVElopment REPORT 2006: EQUiTy AND DEVELOPMENT 11 (2005) (citing a study showing that undersized Jamaican children suffered from "lower levels of cognitive development than those of normal height," but that enhanced nutrition and mental stimulation essentially wiped out the disadvantage over twenty-four months).

96. Nadide Sevil Halıc1-Tülüce et al., Is Income Relevant for Health Expenditure and Economic Growth Nexus?, 16 INT'L J. HEALTH ECON. MGMT. 23 (2016).

97. See Steven A. Ramirez, Endogenous Growth Theory, Status Quo Efficiency and Globalization, 17 BERKELEY LA RAZA L.J. 1 , 7 (2006) ("Nations that build human capital, reduce economically corrosive inequality, and build institutions to support the exploitation of human ingenuity, outgrow those that neglect these props to free market capitalism."); Steven A. Ramirez, Bearing the Costs of Racial Inequality: Brown and the Myth of the Equality/Efficiency Trade-Off, 44 WASHBURN L.J. 87, 87-88 (2004) (citing Phillipe Aghion et al., 37 J. ECON. LIT. 1615, 1615 (1999) ("[T] he view that inequality is growth-enhancing has been further challenged by a number of empirical studies, often based on cross-country regressions of GDP growth on income inequality. They all find a negative correlation between the average rate of growth and a number of measures of inequality.")) ("[T]here is a growing body of economic science that looks beyond mere market theory to clarify the endogenous factors associated with growth; economists pursuing endogenous growth theory have increasingly shown that inequality threatens growth and stability.").

98. Indeed, recent economic learning suggests that economic inequality can operate in a runaway fashion unless disrupted by law. THOMAS PIKETTY, CAPITAL IN THE 21st CENTURY 1 (2014). 
economic inequality led to a breakdown in the rule of law as concentrated wealth wielded excessive influence over law and regulation for their own benefit at the expense of more diffused groups. ${ }^{99}$ That result has long been viewed by economists as harmful to the rule of law and conducive to corruption; elites use their economic power to entrench themselves and their progeny at the apex of an economy through legal and regulatory subversion. ${ }^{100}$ Since then economists have empirically proven this very dynamic in the context of the fall of communist Europe and during the Gilded Age in the United States. ${ }^{101}$

In fact, the Great Financial Crisis provides a textbook example of the macroeconomic carnage that occurs when too much wealth is concentrated in too few hands, as "[e]lite influence supplanted the rule of law and secured irrational indulgences." 102 High economic inequality leads to more corruption, ${ }^{103}$ as well as creating opportunities for entry into lucrative social networks that facilitate the cultural capture of governing elites. ${ }^{104} \mathrm{In}$ short, high economic inequality will lead to growth-delaying elites focused more on rigging the system in their favor than on assuring that society achieves widely distributed macroeconomic growth. ${ }^{105}$

99. Mancur Olson, The Logic of Collective Action: Public Goods And the Theory of GROUPS 2, 11, 165 (rev. ed. 1971) (stating that diffused interest groups will not organize to influence public goods like law because rational actors will instead assume that they can free ride on the efforts of others).

100. Edward Glaeser et al., The Injustice of Inequality, 50 J. MONETARY ECON. 199, 200 (2003) ("[I]f political and regulatory institutions can be moved by wealth or influence, they will favor the established, not the efficient.").

101. Id. (finding that the Gilded Age in the United States and the transition economies of the Eastern Bloc featured high economic inequality and an accompanying erosion in the rule of law).

102. RAMIREZ, supra note 15 , at 5 .

103. ERic M. Uslaner, Corruption, Inequality, and the Rule of Law: The Bulging POCKET MAKES THE EASY LIFE 26-31 (2010) (finding that high inequality leads to greater corruption and threatens to lead to an inequality trap unless disrupted by universal social welfare programs and universal education).

104. As James Kwak highlights:

[C]ultural capture may simply be harder than traditional capture to protect against. In the traditional capture model, a regulator who sides with one interest group out of self-interest would still accept a better offer from another interest group. When groups or ideas attain prestige of their own, however, and when people identify with groups or adopt ideas in part because of the status they confer, it is considerably harder for those people to identify the sources of their choices. Those choices become sticky and are not vulnerable either to a higher offer or to rational argument about the public interest. And so, although cultural capture may be less reliable than the traditional kind, it can also provide a long-term source of advantage for regulated industries that are able to mobilize it.

James Kwak, Cultural Capture and the Financial Crisis, in Preventing Regulatory CAPture: SPECIAL INTEREST INFLUENCE AND How to Limit IT 71, 98 (David Carpenter \& David A. Moss eds., 2013).

105. Daren Acemoglu \& James A. Robinson, Economic Backwardness in Political Perspective, 100 AM. POL. SCI. REV. 115 (2006) (arguing that elites will oppose technological change and 
Thus, economists also lend great support to the concerns of Pope Francis regarding the pernicious effects of high inequality on the rule of law and to the problem of climate change in particular. Other scholars applied this economic science to the Great Financial Crisis. ${ }^{106}$ The basic problem is a small number of powerful individuals imposing massive costs on the less powerful and society in general (mounting to trillions) while pocketing windfall compensation payments (perhaps just a few billion). ${ }^{107}$ Pope Francis innovatively applies this reality to the issue of global warming. ${ }^{108}$ The reality driving global warming denials is the raw profitability of selling underpriced carbon-based fuels. ${ }^{109}$

This narrative matches the approach of the World Bank to facilitating economic growth and development. ${ }^{110}$ The World Bank occupies a key position in the global economy as guarantor of global economic growth and development. ${ }^{111}$ The victorious powers of the West established the World Bank to help revive the global economy from the ashes of World War II. ${ }^{112}$ The World Bank takes a strong stance in favor of level playing fields and against unearned privilege. ${ }^{113}$ It, like Pope Francis, speaks

economic development when their incumbency advantages are threatened and finding historical evidence in support of this dynamic).

106. RAMIREZ, supra note 15 , at 35-38.

107. $I d$. at xiv.

108. As Pope Francis puts it:

$[\mathrm{M}]$ any professionals, opinion makers, communications media and centres of power, being located in affluent urban areas, are far removed from the poor, with little direct contact with their problems. They live and reason from the comfortable position of a high level of development and a quality of life well beyond the reach of the majority of the world's population. This lack of physical contact and encounter, encouraged at times by the disintegration of our cities, can lead to a numbing of conscience and to tendentious analyses which neglect parts of reality. At times this attitude exists side by side with a "green" rhetoric. Today, however, we have to realize that a true ecological approach always becomes a social approach; it must integrate questions of justice in debates on the environment, so as to hear both the cry of the earth and the cry of the poor.

Pope Francis, Laudato Si', supra note 27, para. 49.

109. See Bradley Olson et al., Oil, Coal Seen as Winners With Donald Trump Victory, WaLl ST.

J. (Nov. 9, 2016), https://www.wsj.com/articles/oil-coal-seen-as-winners-with-trump-victory1478693338 [https://perma.cc/36YA-6N4X] (reporting that "Donald Trump's surprise victory fanned expectations in the energy industry that he would clear the path for new pipelines, end U.S. participation in global climate change pacts and undo environmental regulations to boost American coal mining" and "that the president-elect would roll back years of Obama administration policies buoyed investors in fossil fuels companies Wednesday-while sending shares of top wind and solar power firms tumbling").

110. See generally Ramirez, supra note 78 , at 714.

111. See generally Steven A. Ramirez, American Corporate Governance and Globalization, 18 BERKELEY LA RAZA L.J. 47 (2007).

112. Id. at 60-62.

113. WORLD BANK, supra note 91, at 2 ("Institutions and policies that promote a level playing field - where all members have similar chances to be socially active, politically influential, and economically productive — contribute to sustainable growth and development."); id. at 11 ("Actions to 
against high economic inequality and corruption. ${ }^{114}$ The World Bank recognizes that high inequality leads to a breakdown in the rule of law, as elites seek to entrench themselves rather than compete against potential economic rivals. ${ }^{15}$ Finally, the Bank views poverty, particularly childhood poverty, as suspect and economically dangerous and not like an immutable characteristic of capitalism or in any way "normal."116

Economic science also supports the attainability of Pope Francis's vision of a more inclusive and sustainable economy with lower inequality. Authoritative voices recognize that a carbon tax, for example, could be structured in a way that both lowers carbon emissions and reduces poverty. ${ }^{117}$ High economic inequality harms macroeconomic performance and human development, meaning that the Pope's vision is fundamentally sound in terms of growth and important metrics of well-being. ${ }^{118}$ Thus, a more socially just economy actually supports sustainable macroeconomic performance. ${ }^{119}$

Such a sound system of capitalism also benefits from maximum political sustainability. When economic output sputters or is distributed in accordance with perceptions of a high degree of unfairness, then extremism from either the far right or far left gains traction and commitment to free markets, private property, and freedom of contract wanes in favor of statism. ${ }^{120}$ Thus, true capitalists, with full view of historic realities, should welcome the message of Pope Francis. ${ }^{121}$

equalize opportunities in formal education need to ensure that all children have acquire at least a basic level of skills necessary to participate in society and today's global economy.").

114. $I d$. at 7-9 (finding that " $[\mathrm{w}]$ ith imperfect markets, inequalities in power and wealth translate into unequal opportunities, leading to wasted productive potential and to an inefficient allocation of resources" and "economic and political inequalities are associated with impaired institutional development").

115. Id. at 2 ("[W]hen budgetary allocations benefit mainly the politically influential, and when the distribution of public services favors the wealthy, both the middle and poorer groups end up with unexploited talent. Society, as a whole, is then likely to be more inefficient and to miss out on opportunities for innovation and investment.").

116. Id. at 11 ("Evidence supports the view that investing in early childhood has large impacts on children's health and readiness to learn and can bring important economic returns later in lifeoften greater than investments in formal education and training.").

117. See sources cited supra, notes 16, 18. See also Erwin L. Corong, Tariff Reductions, Carbon Emissions, and Poverty: An Economy-Wide Assessment of the Philippines, 25 ASEAN ECON. BULL. 21 (2008) (showing "that carbon taxes not only compensate for the foregone tariff revenue, but also reduce poverty and increase welfare whenever the generated carbon tax revenue is used to reduce income taxes").

118. Ramirez, supra note 10 , at 216-18.

119. Id.

120. Benjamin M. Friedman, The Moral Consequences of Economic Growth 4-15 (2005).

121. Steven A. Ramirez, The Law and Macroeconomics of the New Deal at 70, 62 MD. L. REV. 525-27 (2003). 
Otherwise they compromise the viability of the very system they claim to favor.

The distance between Pope Francis, The World Bank (a bastion of capitalism), and the best learning from economics on growth and development disappears upon a careful reading. Suspicion of privilege, poverty (especially childhood poverty), power, and growth-retarding elites reigns in the pronouncements of all three sources. ${ }^{122}$ Indeed, the Pope even echoes Adam Smith, the misappropriated patron saint of laissez-faire. ${ }^{123}$ The best learning available fully supports the teachings of Pope Francis. ${ }^{124}$

In the next Part, this Article explores whether the above theory and empirical learning captures reality. Specifically using childhood poverty as a proxy for inclusive versus exclusive capitalism, the next Part of the Article will test childhood poverty against inequality-adjusted human development. Any guesses on whether high levels of childhood poverty are economically healthy?

122. The Pontiff's teachings on inclusive capitalism also accord with The Commission on Growth and Development. This commission included policymakers and economists from around the world and sought to create a synthesis of the best learning on economic growth and superior human well-being outcomes for humanity. Two Noble laureates, including Michael Spence (the Chair of the commission), helped guide the work of the commission. THE COMMISSION ON GROWTH AND

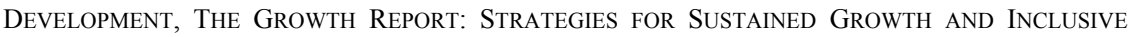
DEVELOPMENT 1-5 (2008) (finding that nations achieve high growth through "impressive rates of public investment-in infrastructure, education, and health. Far from crowding out private investment, this spending crowds it in. It paves the way for new industries to emerge and raises the return to any private venture that benefits from healthy, educated workers, passable roads, and reliable electricity.") [hereinafter SPENCE COMMISSION]. Echoing Pope Francis, the commission found that nations must secure "equality of opportunity" and contain economic inequality. The commission even voiced concerns that high inequality can lead to violence and divisive politics that can harm growth. Id. at 7 . "Inequality of opportunity ... can be toxic.... especially ... if opportunities are systematically denied to a group due to its ethnicity, religion, caste, or gender." Id. at 62 .

123. SмIтH, supra note 21.

124. For example, science fully vindicates the Pope's position that global warming demands a global solution:

More generally, if local sea level rise is the problem in a given city, then reducing that city's emissions is an ineffective policy mechanism for dealing with it. Budgets being limited, the city might be better off building barrier walls and drainage systems. On the other hand, if global emissions reduction is the goal, then cities are an inefficient policy platform for achieving it. Consequently, national policy that relies on subnational governments will likely fail to meet national pledges to global mitigation goals, because those goals will be displaced by increasingly urgent local adaptation needs. This is not a call for first-world cities to save themselves by abandoning mitigation for adaptation; rather, the conflicting pressures on local governments show that collective solutions based on national (and potentially global) policies are needed to adequately limit global emissions. Efforts by cities and other subnational governments will not be enough.

Mark Alan Hughes et al., Cities Can't Lead on Climate Change Mitigation, Bull. ATOMIC SCIENTISTS (Feb. 28, 2017), http://thebulletin.org/cities-cant-lead-climate-change-mitigation 10547 [https://perma.cc/GK6U-8HJ9]. 


\section{THE ECONOMIC REALITY OF SOCIALLY JUST SYSTEMS}

Inclusive systems of capitalism (the concept consistently used by Pope Francis) that tend towards equal opportunity and less economic inequality typically deliver superior inequality-adjusted human development outcomes. ${ }^{125}$ Thus, for example, one sound measure of social justice and inclusion is childhood poverty and well-being. ${ }^{126}$ A society that fails to provide a decent life and economic opportunity for each of its children is both morally and economically backwards. ${ }^{127}$ This measure, from a social justice perspective, rests on the fact that children subjected to poverty cannot possibly bear any moral blame for their predicament. ${ }^{128}$ Further, to the extent poverty (and wealth) persists across generations, it suggests real problems with the degree of equal opportunity available within societies. ${ }^{129}$ If each child within a society lives well and enjoys meaningful opportunities for educational advancement, then such a

125. Ramirez, supra note 10 , at $216-18$.

126. The United States fails miserably to adequately provide for its children of color, allowing festering racial hierarchy to relegate nearly forty percent of its African American children to swelter in poverty and over thirty percent of its Latino/a children. Eileen Patten \& Jens Manuel Krogstad, Black Child Poverty Rate Holds Steady, Even as Other Groups See Declines, Pew Res. CTR. (July 14, 2015) http://www.pewresearch.org/fact-tank/2015/07/14/black-child-poverty-rate-holds-steadyeven-as-other-groups-see-declines/ [https://perma.cc/YX2B-2MG8].

127. Indeed, care for children constitutes a human rights obligation. "In all actions concerning children, whether undertaken by public or private social welfare institutions, courts of law, administrative authorities or legislative bodies, the best interests of the child shall be a primary consideration." United Nations Convention on the Rights of the Child, Art. 3, Nov. 20, 1989, 1577 U.N.T.S. 3 (entered into force Sept. 2, 1990) (ratified by every nation except the United States and Somalia). The Commission on Growth and Development found that childhood poverty impedes economic performance. SPENCE COMMISSION, supra note 118, at 6 ("[I]f children are undernourished in the womb or in infancy, their cognitive development can be permanently impaired. This reduces their productivity and their ability to benefit from an education.").

128. As stated by UNICEF:

Questions of fairness and social justice have a special resonance when inequalities among children, rather than adults, are the focus of attention. Social inequalities among adults may be justifiable if they have arisen through fair competition and under conditions of equality of opportunity. But when it comes to children, the social and economic circumstances they face are beyond their control, and so differences in merit cannot reasonably be advanced as justification for inequalities among them. In addition, few dispute that childhood experiences have a profound effect not only on children's current lives, but also on their future opportunities and prospects. Likewise, social and economic disadvantages in early life increase the risk of having lower earnings, lower standards of health and lower skills in adulthood. This in turn can perpetuate disadvantage across generations. None of this is the fault of the child.

UNICEF, FAIRNESS FOR CHILDREN: A LEAGUE TABLE OF INEQUALITY IN CHILD WeLl-Being IN RICH COUNTRIES 2 (2016), https://www.unicef-irc.org/publications/pdf/RC13_eng.pdf [https://perma.cc/6S8W-2MMF] [hereinafter FAIRNESS FOR CHILDREN 2016].

129. Mobility in the United States, for example, is very low relative to the rest of the developed world and relative to its own history, suggesting less a competitive meritocracy than severe elite entrenchment. See generally THOMAS M. SHAPIRO, TOXIC INEQUALITY: HOW AMERICA's WEALTH Gap Destroys Mobility, DeEPens the Racial Divide, And Threatens Our Future (2017). 
society will likely create more innovations than other societies; on the other hand, children living in poverty suffer diminished social and economic opportunities in a way that will invariably harm economic outcomes and human development. ${ }^{130}$

There is very wide variation among countries with respect to child poverty and well-being, even among developed nations. Thus, in Switzerland childhood deprivation affects only four percent of all children. ${ }^{131}$ Meanwhile, in Bulgaria, about fifty percent of children live in deprived households. ${ }^{132}$ This variation permits a test of a fundamental thesis of this Article: using measures of childhood poverty and deprivation as a proxy for an inclusive capitalism, can differences in inequality-adjusted human development be correlated with differences in child well-being across nations?

Indeed, they can. Thus, Switzerland as a society provides for the well-being of their children better than any other nation in the world in terms of child deprivation. ${ }^{133}$ Switzerland also sports a very high inequality-adjusted human development index. ${ }^{134}$ In fact, only two nations outperform Switzerland in the Inequality-adjusted Human Development Index (IHDI) for 2015: Norway and the Netherlands. ${ }^{135}$ They also hold enviable scores in taking care of their children: Norway ranks very close to the leader (Switzerland) and the Netherlands is just a small degree behind Norway. ${ }^{136}$ Thus, the top three nations in IHDI (that is, the nations that provide the highest level of human development to its citizens) also do a remarkably good job of investing in their economic future-their children. ${ }^{137}$ While the correlation is not perfect, there is powerful evidence that those nations that take care of their children also tend to deliver very high levels of inequality-adjusted human development.

On the flip side, the United States illustrates the same point: nations that allow their children to wallow in deprivation do not perform well in delivering the great mass of their people an advanced standard of living

130. Id.

131. UNICEF, FAIRNESS FOR CHILDREN: A LEAGUE TABLE OF INEQUALITY IN CHILD WELLBEING IN RICH COUNTRIES 17 (2011) [hereinafter FAIRNESS FOR CHILDREN 2011].

132. Id.

133. FAIRNESS FOR CHILDREN 2016, supra note 124, at 17. Note that Switzerland, Norway, Sweden, and the Netherlands are among the top five scores for child deprivation for all children but other nations may have tied scores with those nations. Id.

134. United Nations Development Programme: Human DeVelopment Report 2015 : WORK FOR HUMAN DEVELOPMENT 216 (2015) [hereinafter IHDI RANKING] http://hdr.undp.org/sites/default/files/2015_human_development_report_0.pdf

[https://perma.cc/6PZE-4DNP] (showing Switzerland as the third highest nation in the world in terms of IHDI).

135. Id.

136. FAIRNESS FOR CHILDREN 2016, supra note 124, at 17.

137. IHDI RANKING, supra note 130, at 216. 
when measured in terms of IHDI. ${ }^{138}$ The United States holds a middling position at best in terms of giving its people a broad degree of prosperity, education, and longevity - ranking twenty-eighth in the world in providing a broadly available and high standard of living. ${ }^{139}$ Investment in children is the most important investment a society can make because ideas drive growth and once poverty destroys human potential the loss can become a permanent drag on growth. ${ }^{140}$

In fact, in terms of all possible human capital investments, investments in early childhood development programs boast the highest rates of returns. According to economist and Nobel laureate James J. Heckman: "Investing in disadvantaged young children is a rare public policy initiative that promotes fairness and social justice and at the same time promotes productivity in the economy and in society at large." Furthermore, "[e]arly interventions targeted toward disadvantaged children have much higher returns than later interventions such as reduced pupil-teacher ratios, public job training, convict rehabilitation programs, tuition subsidies, or expenditure on police." ${ }^{142}$ While all such human capital investments pay more than their cost investing in the most socioeconomically disadvantaged children holds the highest degree of economic benefits. ${ }^{143}$ Given the economics of such investments in the disempowered, one can only wonder why so much of the world ignores the Pope's injunctions against childhood poverty. ${ }^{144}$

138. In a broad-based measure of child wellbeing, the U.S. ranked eighteenth in terms of delivering broad-based quality of life outcomes. FAIRNESS FOR CHILDREN 2016, supra note 124, at 12.

139. IHDI RANKING, supra note 130, at 216.

140. "The timing of education spending matters as well as the amount. Investments in early childhood raise the returns to investments later in life - children must learn how to learn. If they do not, they may never regain the lost ground, leaving a society sapped of potential and scarred by inequality." SPENCE COMMISSION, supra note 118, at 38.

141. James J. Heckman, Skill Formation and the Economics of Investing in Disadvantaged Children, 312 SCIENCE 1900, 1902 (2006).

142. Id.

143. Id. ("Although investments in older disadvantaged individuals realize relatively less return overall, such investments are still clearly beneficial. Indeed, the advantages gained from effective early interventions are sustained best when they are followed by continued high-quality learning experiences.").

144. See, e.g., Pope Francis, Address of His Holiness Pope Francis To the Executive Board of the World Food Programme (June 13, 2016), http://w2.vatican.va/content/francesco/en/ speeches/2016/june/documents/papa-francesco_20160613_sede-programma-alimentare-

mondiale.html [https://perma.cc/6SH6-GQ4T] ("We need to 'de-naturalize' extreme poverty, to stop seeing it as a statistic rather than a reality. Why? Because poverty has a face! It has the face of a child; it has the face of a family; it has the face of people, young and old."); Pope Francis, Homily of His Holiness Pope Francis, Solemnity of the Nativity of the Lord (Dec. 24, 2016), https://w2.vatican.va/content/francesco/en/homilies/2016/documents/papa-francesco_20161224_ omelia-natale.html [https://perma.cc/38UP-39RM] ( "Let us allow the Child in the manger to challenge us, but let us also be challenged by all those children in today's world who are lying not in a crib, caressed with affection by their mothers and fathers, but in squalid 'mangers that devour 
The bottom line is that, tested against the quality of human development on a widely dispersed basis, it simply does not make sense to tolerate childhood deprivation and poverty. Children living and raised in poverty cannot be productive workers and cannot be expected to innovate as required for economic growth. ${ }^{145}$ Yet, in an economy marred by high inequality and the use of power for profit and plunder, ${ }^{146}$ one would expect the most disempowered to suffer the greatest disadvantage. ${ }^{147}$ As economist and Nobel laureate Angus Deaton stated: "Income inequality is rising rapidly in many rich countries and in many poor countries. In many places, the benefits of economic growth are accruing to a tiny minority who are already greatly advantaged."148

The economic exclusion implicit in childhood poverty drags down economic growth in a particularly immoral and economically corrosive way. ${ }^{149}$ Estimates suggest a total macroeconomic cost exceeding a half of a trillion dollars per annum in the U.S. alone. ${ }^{150}$ These costs arise from impaired productivity, crime, and healthcare. ${ }^{151}$ "In a nation where equal opportunity is a widely accepted goal for public policy, inequities associated with children growing up in poverty are troubling."

dignity ....' Let us allow ourselves to be challenged by those children who are not allowed to be born, by those who cry because no one relieves their hunger, by those who hold in their hands not toys, but weapons."); see also Pope Francis, Evangelii Gaudium, supra note 28, para. 197 ("God's heart has a special place for the poor, so much so that he himself 'became poor.' . . The Saviour was born in a manger, in the midst of animals, like children of poor families.").

145. See, e.g., Harry J. Holzer et al., The Economic Costs of Childhood Poverty in the United States, 14 J. CHILDREN \& POVERTY 41, 52 (2008) (estimating economic costs of childhood poverty in the United States arising from lost productivity, crime and healthcare costs to total $\$ 500$ billion).

146. "As the rich get richer and richer, it gets easier and easier for them to buy political favors. They can twist the media, elected officials, and government agencies to do their bidding. They vote with their money, which makes a mockery of our democratic 'one vote, one person' creed." LES LEOPOLD, RunAwAY INEQUALITY: AN ACTIVIST'S GuIDE TO ECONOMIC JUSTICE 2 (2015). In the words of economist Angus Deaton, our economy is "one that is driven by the unproductive rent-seeking of those who are already rich and powerful. Those people get rich not by creating anything, but by taking away from everyone else. The inequality that comes from this kind of crony capitalism is a cancer that threatens us all." 2015 Nobel Prize in Economics: "Inequality derived from crony capitalism is a cancer”, ROME REP. (Nov. 29, 2016) [hereinafter Deaton Report], http://www.romereports.com/2016/11/29/2015-nobel-prize-in-economics-inequality-derived-fromcrony-capitalism-is-a-cancer [https://perma.cc/DCJ6-D86T].

147. For example, "today the U.S. is the most unequal country in the developed world. We have the most child poverty and homelessness. We have more people in prison than China and Russia. And Americans are less upwardly mobile than most Europeans." LEOPOLD, supra note 142, at 3.

148. Deaton Report, supra note 142.

149. Holzer et al., supra note 141, at 41-42.

150. Valerie Strauss, The Cost of Child Poverty: \$500 Billion a Year, WASH. PosT (July 25, 2013), https:/www.washingtonpost.com/news/answer-sheet/wp/2013/07/25/the-cost-ofchild-poverty-500-billion-a-year/?utm_term=.f742ce32ac8c [https://perma.cc/2E2D-J6RS] (noting that the U.S. suffers the highest childhood poverty rate of all developed countries except Romania).

151. Holzer et al., supra note 141, at 41-42.

152. $I d$. at 41 . 
However, "[o]ur $\$ 500$ billion is large enough to suggest that the investment of significant resources in poverty reduction might be more socially cost-effective over time than we previously thought." 153 In other words, the Pope's emphasis on a more inclusive capitalism is not only sound from a moral perspective, it also rests on a sound macroeconomic perspective.

Consequently, the vision of Pope Francis once again comports with those versions of capitalism that serve their populations the best. ${ }^{154}$ Indeed, the compelling evidence in support of the teachings of Pope Francis suggests that much of the criticism of his key statements on inequality and the environment is simply motivated by the self-interested behavior of political and economic elites rather than any objective assessment of the evidence in support of the Pope. ${ }^{155}$ Others may simply accept the current comfort of existing social and economic hierarchies regardless of evidence. ${ }^{156}$ For such groups, the key is not learning, but profits now, to maintain the status quo.

\section{CONCLUSION}

Pope Francis's application and extension of longstanding Catholic social teachings to compelling contemporary problems helps to focus attention on such problems. Global economic inequality and growing economic inequality in the United States has already imposed trillions in excess costs on the economy for the enhanced wealth of a relative handful of global elites. Now global warming promises another massive wealth transfer of trillions of dollars from the global economy and the poorest among us for the benefit of a small number of energy industry elites.

153. Id. at 53 .

154. As stated by the Commission on Growth and Development:

Growth is not an end in itself. But it makes it possible to achieve other important objectives

of individuals and societies. It can spare people en masse from poverty and drudgery.

Nothing else ever has. It also creates the resources to support health care, education, and

the other Millennium Development Goals to which the world has committed itself. In short,

we take the view that growth is a necessary, if not sufficient, condition for broader

development, enlarging the scope for individuals to be productive and creative.

SPENCE COMMISSION, supra note 118, at 1.

155. Robert J. Brulle, Institutionalizing Delay: Foundation Funding and the Creation of U.S. Climate Change Counter-Movement Organizations, 122 ClimatiC CHANGE 681 (2014) (finding that untraceable foundation funding ("dark money") previously linked to oil companies, fuels climate change denial).

156. Kristi M. Jylhä \& Nazar Akrami, Social Dominance Orientation and Climate Change Denial: The Role of Dominance and System Justification, 86 PERSONALITY \& INDIVIDUAL DIFFERENCES 108, 110-11 (2015) ("[C]limate change seems to be disputed due to motivation to protect social as well as human-nature hierarchies at least with the set of variables used in the present study."). 
There is a massive body of evidence supporting the teachings of Pope Francis. The teachings also are fully in accord with Catholic teaching from decades, even centuries, past. The world of economics also fully supports the key points that high inequality and un-impounded costs creates a drag on growth and market distortions within the economy.

Consequently, it is clear that the degree of controversy the Pope's statements have stirred-up arise not from an erroneous understanding of the problems nor from any incorrect reading of the economic evidence in support of His Holiness's teachings. The controversy arises only because Pope Francis speaks on behalf of the disempowered to question the legitimacy of the current distribution of economic and political power, and how that power is used to accumulate more wealth at the expense of the rest of humanity.

Nevertheless, Pope Francis, as a high-profile global religious leader, adds a compelling moral and spiritual foundation to the already compelling economic case in favor of reduced economic inequality and poverty. When the moral case for reduced inequality is viewed in conjunction with the scientific case, the full reprehensibility of the current paradigm becomes clear. The status quo is at once immoral and macroeconomically backwards. Corporate and financial elites hold far too much power to pursue plunder for profit and too much sway over the global economy and humanity; that power must urgently be reduced. Global warming in particular highlights the urgency of these issues. 